\title{
MORPHOPHONOLOGICAL PROCESSES OF THE C'LELA NOUN
}

\author{
Muhammad Ango Aliero
}

\begin{abstract}
This article discusses some aspects of the morphophonology of C'lela nouns. It will be shown that the addition of inflectional affixes to certain noun stems in C'lela, sometime motivate certain phonological processes. The analysis demonstrates that when the plural suffix $[-\mathbf{n V}]$ attaches to animate nouns in C'lela, it triggers certain morphophonological processes such as vowel copying, metathesis, vowel lengthening, final-vowel deletion, and initial-consonant deletion. For example, the paper argues that in plural formation, stem final-vowel sometimes undergoes metathesis when the plural marker /-nV/ attaches to a noun stem, thus; $\underline{\text { àrmá }}$ 'man' $+n a$ becomes à $\underline{\text { rám }}$-n $n \underline{a}$ 'men, as against the rule of vowel epenthesis assumed in (Dettweiler 2012). In addition, the analysis discovers that the processes of metathesis and vowel lengthening are simply conditioned by phonological structure.
\end{abstract}

Key Words: morphophonology, vowel copying, metathesis, vowel lengthening

\section{Résumé}

Ce travail de recherche parle de quelques aspects de la morphophonologie de noms en C'lela. Il montrera que quand les affixes infléchis sont ajoutés à certains noms (radicaux de noms) en C'lela, ils motivent quelquefois certains processus phonologiques. L'analyse démontre que si le pluriel du suffixe [-nV] s'attache aux noms inanimés en C'lela, il declenche quelques processus morphophonologiques tels que copiage de voyelle, métathèse, allongement de voyelle, délétion de la voyelle finale et la délétion consonne. Par exemple, la recherche soutient que dans la formation du pluriel, voyelle finale du radical des fois subit une métathèse si le marqueur du pluriel $[-\mathrm{nV}]$ s'attache à un radical du nom, ainsi ; $\underline{a} r m \underline{a}$ "homme" + na dévient àrá́m-nà "hommes" au contraire de règles d'épenthèse de voyelle postulées dans (Dettweiler 2012). L'analyse découvre que les processus de la métathèse et l'allongement de voyelle sont conditionnés par la structure phonologique.

http://dx.doi.org/10.4314/gjl.v4i1.1 


\subsection{Introduction}

C'lela, listed with the code ISO 639-3 [dri] (Lewis et al. 2015), belongs to group 7 (G) of Western-Kainji, Benue-Congo, Volta-Congo, Atlantic-Congo, Niger-Congo together with Reshe, Kamuku, Kambari, Basa, Baushe, Gurmana, Banganci (Lyase or Gwamhi-Wuri cluster), Fakkanci (Peka-Kori-Wipsi-Geeri Cluster) and Duka (Williamson 1989, Gerhardt 1989). However, more recent classification places C'lela as Northwest, Kainji subgroup of Benue-Congo, together with Hun-Saare (Duka), UtMa'in (Fakai), and other languages within Gwamhi-Wuri cluster (McGill and Blench 2012, Lewis et al. 2015). It is the language of the Lelna (or the Dakarkari) people spoken by a majority of the inhabitants of Zuru emirate, located in the eastern part of Kebbi State, Nigeria. This article examines the phonological processes taking place within a noun stem in C'lela. Henceforward, the first mention of any language will include its ISO 639-3 codes in square brackets.

The C'lela noun consists of stem(s) and affixes. The majority of the nouns have class affixes in both singular and plural, but sometimes, nouns may either have a singular or plural form only. Descriptions of the noun class system exist in Hoffman (1967), Dettweiler (2012) and Aliero (2013). This paper focuses on the plural suffix [$\mathrm{nV}]$.

It is to be noted that in the C'lela writing system, noun prefixes are marked with the close-mid central (schwa) vowel [ə] as proposed by Hoffman (1976: 240-241). The schwa vowel is post-posed on the noun class markers at phonetic level in order to distinguish them from pronouns and pronominal affixes (Dettweiler 2012). However, the Committee for the Standardization of C'lela Orthography (CSCO) prefers the use of an apostrophe /'/ in place of the schwa vowel when making a citation. The CSCO perhaps prefers the use of an apostrophe in place of a schwa for reasons of familiarity and ease of writing and/or typing. Certainly, the schwa vowel is a special character that is hardly to be found on an ordinary typewriter, which the CSCO probably used in its work.

Yet again, probably based on the principles of convenience, harmonization and familiarity/acceptability as proposed by experts such as Williamson (1984), Simons (1994) and Barnwell 1998); the CSCO suggests the use of underscored e, to represent the phoneme $[\varepsilon]$, o to represent $[0]$ and a to represent the near close-mid central vowel [ə] in the current language writing system. Some related Kainji languages like Kambari [tvd] (Stark 2010, Crozier 2012), Tyap [kcg], and Tsureshe [res] (Harley 2012, Blench and McGill n.d) have adopted this type of alternate vowel representation. In these languages, like C'lela, the schwa central phoneme [ə] is orthographically represented as the underlined symbol a ; while the $\underline{\text { Ut}}-\mathrm{Ma}$ 'in [gel] current orthography uses the underlined vowel $\underline{u}$ in place of the near close-mid central 
vowel [э] (Smith 2007). This study adapts the current proposed writing system for C'lela.

In the description of the morphophonological problems presented by the data in this work, we adopt the generative phonology framework Chomsky and Halle (1968); however, in some instance, the paper attempts combining it with a nonlinear Autosegmental approach Goldsmith (1976) to account for some data, specifically in vowel lengthening.

Additionally, the study adopts a stem method or unitary base hypothesis as against root method. In the unitary hypothesis, the base of a given word formation process comprises a unitary and specified morphosyntactic word with no disjunction in the specification of the base (Baba 1998, Aronoff 1976). Therefore, in accounting for the morphophonological process in this study, we consider a complete word (stem) as the basic underlying form. The paper is organized into four sections: Section one introduces the paper. Section two examines the phonological problems that are motivated when an inflectional affix comes in contact with a noun stem, while section three forms the conclusion.

\subsection{Morphophonological Processes of the C'lela noun}

In C'lela, the plural suffix [-nV] is the commonly occurring affix that marks plurals for animate nouns. The study shows that the addition of the plural suffix marker /-nV/ to animate noun stems in C'lela sometimes triggers various phonological processes, which include vowel copying, metathesis, vowel lengthening, and final-vowel deletion, each of which we discuss below.

\subsection{Vowel Copying in Plural Formation}

A process where certain affixes have vowels that derive their pronunciation from nearby vowels is identified as "vowel copying" (Stark 2010:53). Vowel copying, sometimes called vowel harmony is considered as an assimilatory process which typically involves vowels which occur within a word. This vowel copy harmony often shows assimilation for all vowel quality features affecting backness, rounding, height, and tongue root advancement or retraction, as well as harmony for all vowel place features (Rose and Walker 2011:251-256).

Vowel copying is an archetypical feature of C'lela morphology. The vowel copying process in the language most frequently occurs with the plural suffix [-nV] and past tense suffix $[-\mathrm{kV}]$. It occurs with the perfective suffix as in /rìgà̀+kV/ $\rightarrow$ [rìgkà $]$, $/$ bèké $+\mathrm{kV} / \rightarrow$ [bèkékè] 'jumped over' etc. In the present study, it can be observed that the vowel of the nominal suffix $-\mathbf{n V}$, in each case in example (1), is formed by copying the quality of the final vowel of the noun stem to which it is attached, thus: 


\section{INPUT VOWEL COPY GLOSS}
a. /bíngí-nV/ $\rightarrow$ [bíngínì]
'male donkeys'
b. /zúgdá-nV/ $\rightarrow$ [zúgdà.nà]
'large buttocks'
c. /zìmíná-nV/ $\rightarrow$ [zìmínánà]
'ostriches'
d. /mànkà-nV/ $\rightarrow$ [mànkànà]
'old men'
e. /cóntọ̀-nV/ $\rightarrow$ [cóntónò]]
'kinds of birds'
$\mathrm{f}$. /mùkú-nV/ $\rightarrow$ [mùkú.nù]
'midges'.

This vowel copying process, as observed from the above examples in C'lela, appears to be a common phenomenon in Niger-Congo as is evident in various languages in the family. Some of the languages that employ vowel-copying mechanism similar to C'lela, albeit not with noun inflection for this type of process include Kambari, a Western-Kainji language. For instance, in Kambari, Stark (2010:53) observes that, when the verbal iterative marker /-sV/ is suffixed to the verb root, the vowel of the suffix copies the features of the vowel that immediately precedes it. The following examples from Auna Kambari show the phonetic outcome of the addition of the suffix to the verb root, as given in (2) below:

\section{Kambari}
a. dàná 'say'
b. kècé 'count'
[dànì-sá] /dàná + sV/ 'say repeatedly'
c. sòró 'pound'
[kècì-sfé] /kècé $+\mathrm{sV} /$ 'count repeatedly'
[sòrù-só] / sòró $+\mathrm{sV} /$ 'pound repeatedly'
d. sùkú 'send'
[sùkù-sú] /sùkú + sV/ 'send repeatedly'.

(Stark 2010:53)

Equally, the vowel copying process, as observed from the examples in C'lela and Kambari above, occurs in Cicipu [awc], another western-Kainji language. In this language, vowel copying employs when a causative suffix /sA/ attaches to certain verb stems. The following examples in (3) taken from McGill (2009:221) illustrate this.
Cicipu
Verb
Causative
Gloss
a. yuwo 'fall'
yuwo-so 'cause to fall'
b. sukulu 'move'
sukulu-su
c. hina 'ripen'
hini-sa
'cause to move'
'cause to ripen'.

(McGill 2009: 221)

Similarly, the vowel copying process occurs in Igbo [ibo], an Igboid, Benue-Congo language. In Igbo, the process applies when a benefactive suffix /-rV/ attaches to some verb roots (Onukawa 1999:115), as shown in the examples in (4) below. 


\section{Igbo}

(4)

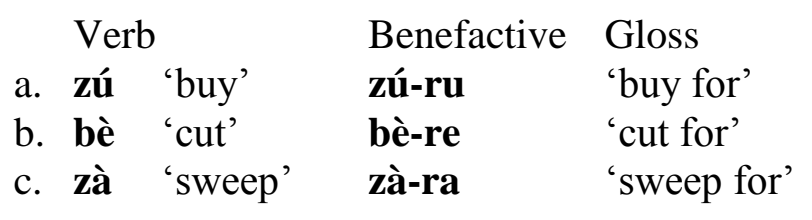

(Onukawa 1999:115-120)

Also in Basa [bas], a Bantu language, vowel copying occurs when a reversive suffix combines with certain verb stems (Hyman 2007: 152), as can be seen in examples (5):

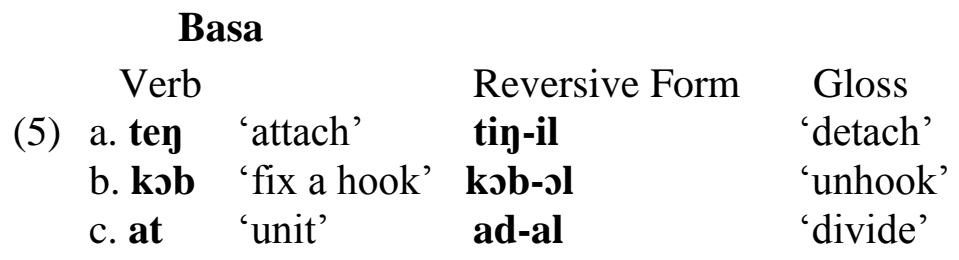

(Hyman 2007:152)

\subsection{Metathesis in Plural Formation}

Metathesis is a Greek term for 'transposition', which refers to re-arranging or reordering of segments, mainly of sounds or syllables in a word. Sometimes it involves re-ordering of words in a sentence (Crystal 2008 and Buckley 2011). Metathesis, according to Chomsky and Halle (1968: 36), "is a perfect common phonological process"; by which the linear ordering of segments switches; in which case the original order is considered the output, and the other order resulting from metathesis, the output (Hume 2001: 1, 2004: 203, 2007: 2). Buckley (2011: 64) observes that although metathesis is perceived as one of the phonological processes, where the specific change is expressed in terms of phonological categories, some types of metathesis require reference to morphological context. He further notes that $\mathrm{CV}$ metathesis often appears to occur in the presence of a particular morphological trigger even if the re-ordering that occurs can be defined phonologically. Hume (2007: 2) further highlights that two sounds usually undergo metathesis under certain conditions which include; perception; structural conditions; contextual probability; word frequency; generalization; and expectation.

Metathesis is of two types: i) adjacent metathesis (or local metathesis) which involves the exchange of two or more contiguous sounds, and ii), the non-adjacent metathesis (long-distance metathesis) where the exchange involves non-contiguous sounds. Adjacent metathesis occurs for some words in C'lela. 


\subsubsection{Adjacent (CV) Metathesis}

We find in C'lela the occurrence of adjacent metathesis where final CV transposes to $\mathrm{VC}$ in a morphological context. From the data below, we may rightly observe that the process of plural formation, which attaches the [-nV] suffix to noun stems, creates the environment for reversal of stem-final, nasal/liquid-vowel sequence in the output. The rule for this CV metathesis in plural formation is that it occurs only on a noun stem that begins with a (C) VC syllable type, and ends in a nasal/liquid-vowel sequence. This results in the syllabification process, characterized by the Sonority Sequencing Principle, which is a model used in "defining the well-formed sequences of phonological segments" (Kenstowicz 1994: 260). This metathesis in C'lela and the rules that motivate the process appear quite unique to C'lela in the Niger-Congo family. Here are some examples:

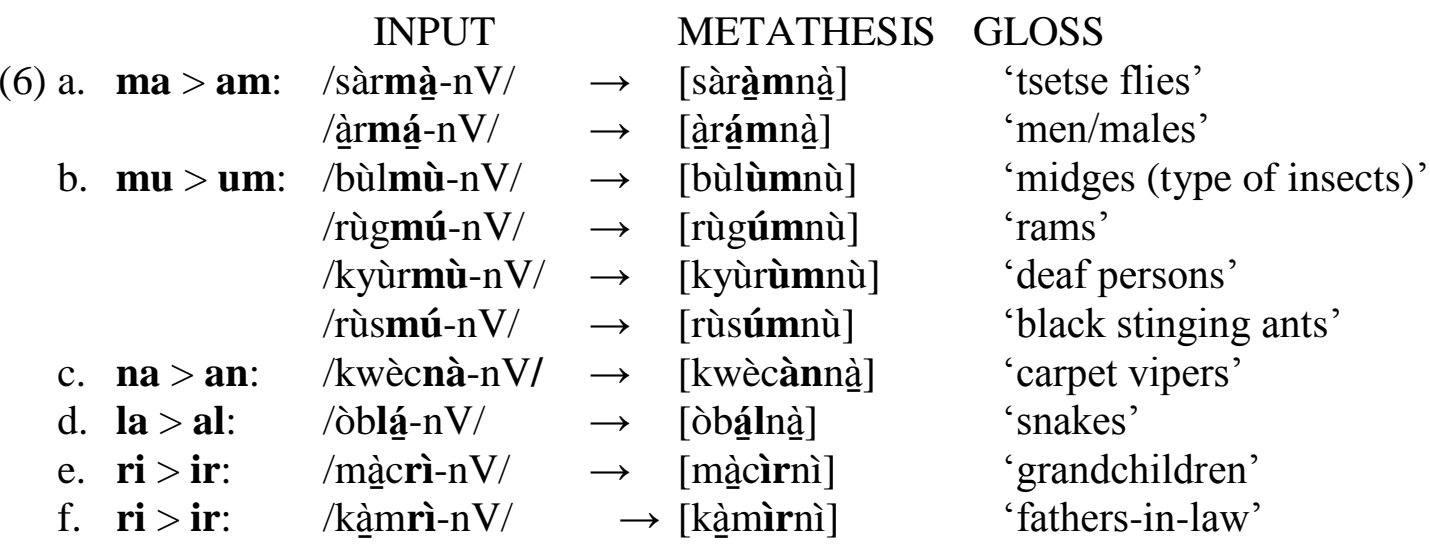

The following rule represents the above adjacent metathesis (e.g. sàràm + nà 'tsetse flies'):

$$
\begin{aligned}
& \text { /sàrmà }+\mathrm{nV} \mathrm{/} \mathrm{input} \\
& \text { /sàrmà }+ \text { nà } / \rightarrow \text { [sàràmmnà] metathesis }
\end{aligned}
$$

Structural Description :

$$
\begin{aligned}
& / \mathrm{s} \quad \text { à } \quad \mathrm{r} \quad \mathbf{m} \text { à }-\mathrm{n} \text { a / } \\
& \begin{array}{llllllllllllll}
1 & 2 & 3 & \mathbf{4} & \mathbf{5} & 6 & 7 & \rightarrow 1 & 2 & 3 & \mathbf{5} & \mathbf{4} & 6 & 7 / \text { output: [sàràmnà̀] }
\end{array}
\end{aligned}
$$

The rule in (7) states that noun stem final CV transposes to VC before a plural suffix.

The metathesis for the nasal/liquid-vowel sequences [ma] and [am], [mu] and [um], [la] and [all] in (6) above show the pattern in the sonority hierarchy that is most preferred in C'lela since metathesis occurs on these forms. We could also assume 
here that the vowels [ $\underline{\mathbf{a}}$ and $\mathbf{u}]$ precede the liquid/nasal [m and $\mathbf{l}]$ sounds in the metathesis because vowels are inherently more sonorous than the nasal/liquid sounds. Other similar metathesis processes obtain in Elmolo [elo], a Kenyan Lowland Cushitic language and Sidamo [sid], a Highland Cushitic language (Hume 2004). In Elmolo, metathesis takes place in the plural formation by the addition of the plural suffix /-o/ to the nouns beginning with the obstruent stop as in (8) below, while in Sidamo, the process occurs before suffixes with initial sonorant /-n/ as shown in (9) taken from (Hume 2004:208).

\section{Elmolo}

(8) a. tikir

SINGULAR PLURAL GLOSS

$\begin{array}{lll}\text { b. deker } & \text { derko } & \text { 'horn' } \\ \text { c. mukul } & \text { mulko } & \text { 'iron'. }\end{array}$

(Hume 2004: 208)

\section{Sidamo}

$\begin{array}{rlll} & \text { INPUT } & \text { SURFACE } & \text { GLOSS } \\ \text { (9) a. } & \text { gud-nonni } & \begin{array}{l}\text { gundonni } \\ \text { b. }\end{array} & \text { dod- nanni } \\ \text { dondanni } & \text { 'he will run' } \\ \text { c. } & \text { it-noommo } & \text { intoommo } & \text { 'we have eaten' }\end{array}$

(Hume 2004:208)

Another robust case of adjacent metathesis, somehow parallel to C'lela, is found in Fur [fvr], a Nilo-Saharan language. In Fur, this type of metathesis is triggered when a mono-consonantal prefix such as /k-/ 'we' is affixed to certain consonant-initial verbs (Hume and Mielke 200: 141). Consider the Fur metathesis where an underlying CV changes to VC under prefixation in (10):

Fur

\begin{tabular}{|c|c|c|c|}
\hline Fur & & & \\
\hline PREFIXATION & & METATHESIS & GLOSS \\
\hline k-ba- & $\rightarrow$ & kab- & 'we drink' \\
\hline k-teer- & $\rightarrow$ & keter- & 'we forge' \\
\hline k-saar- & $\rightarrow$ & kasar- & 'we expose for sale' \\
\hline k-neen & $\rightarrow$ & kenen & 'we bewitch'. \\
\hline
\end{tabular}

(Hume and Mielke 2001:141)

However, Dettweiler (2012: 22) treats this metathesis phenomenon as "epenthesis" of the vowel /a/, which according to him "occurs when necessary to avoid a twoconsonant coda that violates the Sonority Sequencing Principle". This study argues for metathesis rather than vowel epenthesis since the data above do not show insertion 
of an additional sound into such words, but a swap of two sonorous segments on the same segmental tier, which is an important feature of metathesis. After all, there exist catalogues of several non-sonorous two-consonant coda segments that do not undergo metathesis, as is evident in the examples in (11):
(11) a. órgò-nV órgnò 'termites'
b. rùktù-nV rùktnù 'kinds of locust'
c. pèntà-nV pèntnà 'songbirds (bulbul)'
d. zúgdá-nV zúgdánà 'large buttocks'

Consider examples of metathesis in the following sentence structure.

(12) a. nòk-kàn u'rògàncó àrmá go-PST market man

'The man went to the market.'

b. àráám-nà nòk-kàn u'rògàncó

man-PL go-PST market

'The men went to the market.'

(13) a. làgà-m còm kyùrmù

let-me send deaf person

'Let me send the deaf person.'

b. làgà-m còm kyùrùm-nù

let-me send deaf person-PL

'Let me send the deaf persons.'

\subsection{Vowel Lengthening}

There is a situation in C'lela where noun inflection triggers vowel lengthening. In the formation of plurals for animate nouns, the short vowel of monosyllabic noun stems usually undergoes lengthening when the plural suffix /-nV/ attaches to the noun stem.

\section{INPUT}
a. $/ \mathrm{cwẹ̀-nV/} \rightarrow$ [cwẹènè]
b. /gò-nV/ $\rightarrow$ [gòonò]
c. /kò-nV/ $\rightarrow$ [kòonò]
d. $/$ pà-nV/ $\rightarrow$ [pàanà]
e. $/$ pí-nV $\rightarrow$ [píinì]

\section{GLOSS}

'musk shrews'

'white oryxes'

'frogs'

'hawks'

'weevils (grain eating insects)'

We can formulate the vowel lengthening rule in C'lela as in (15) below: 
(15) Vowel Lengthening<smiles>[X]C([X])[X]</smiles>

The rule in (15) specifies that the short vowel of a monosyllabic noun stem may undergo lengthening when followed by a suffix plural marker.

The process in (14) above is analogous to the way in which addition of the plural suffix /-ri/ to the noun stem in Dagaare [dga], a Gur language, is accompanied by high vowel lengthening. Another similar example to the one in C'lela also comes from Cicipu [awc], where in the nominal derivation, the addition of the nominal suffix /-ni/ to verb stem, results in the lengthening of short vowel of the final syllable of the verb.

The vowel lengthening process seems to occur only in isolated languages in the Niger-Congo; however, more evidence for this process could be found in Kainji languages. Compare the following examples of vowel lengthening from C'lela in (14) and those of Dagaare in (16), and Cicipu in (17):

\section{Dagaare}

$\begin{array}{lll}\text { SINGULAR } & \text { PLURAL GLOSS } \\ \text { a. bì } & \text { bíí-rí } & \text { 'child' } \\ \text { b. tì } & \text { tì̀-rí } & \text { 'tree' } \\ \text { c. kù } & \text { kúú-rí } & \text { 'wild rat' }\end{array}$

(Anttila and Bodomo 2007:5)

\section{Cicipu}

VERB

NOUN

GLOSS

(17)
a. kó 'to die'
ù-kóo-ní
'death'
b. ùngó 'to rise'
nùu-úngóo-ní 'resurrection'

(Modified from McGill 2009: 204)

\subsection{Vowel Deletion in the Plural Formation}

The plural formation in C'lela, as already mentioned above, often triggers a phonological process, which deletes a noun-stem-final vowel in front of the plural suffix. This would imply that suffixation of the plural marker /-nV/ to the noun stem, sometimes results in the deletion of the final vowel of such a noun stem. This happens provided that the first syllable of the singular noun is not of (C) VC structure, and that 
its final syllable does not end in a liquid/nasal-vowel sequence, in which case, a process of metathesis occurs.

\section{INPUT VOWEL DELETION GLOSS}
a. /jánká-nV/ $\rightarrow$ [jánknà]
'donkeys'
b. /cà̀wíimà-nV/ $\rightarrow$ [cà̀wíimnàa]
'crocodiles'
c. /hyànnú-nV/ $\rightarrow$ [hyạ̀nsnú]
$\mathrm{d}$. /làgù-nV/ $\rightarrow$ [làgnù]
e. $/$ kácì-nV/ $\rightarrow$ [kácnì]
'monitor lizards'
'rat'
$\mathrm{f}$. /cìckî-nV/ $\rightarrow$ [cìcknî]
'chickens'
g. /kórkótò̀-nV/ $\rightarrow$ [kórkótnò]
'pimples/rashes'
'lice'
$\mathrm{h} . /$ máagè-nV/ $\rightarrow$ [máagnè]
'bricklayers, potters'.

Looking at the examples in (18) above, we can observe, for instance, that the vowel deletion process applies on the noun stem in (18a), jánká 'donkey', because it does not end in a liquid/nasal-vowel sequence even when it begins with a CVC syllable, and it applies on (18b) càiwímà 'crocodiles' because it does not begin with a CVC syllable, even though it ends in a nasal-vowel sequence. This affects several other similar examples as in (18) above. However, metathesis, instead of vowel deletion, may occur on a noun stem whose initial syllable is of (C)VC structure, and the final syllable is of a liquid/nasal-vowel sequence, before a plural suffix as in sàrmà $+n a$ $\rightarrow$ sàràm $\boldsymbol{m}$ - $\underline{\text { à }}$ 'tsetse flies'.

The final vowel deletion rule can be formulated as in (19).

\section{(19) Final Vowel Deletion}

$$
-\mathrm{V} \rightarrow \boldsymbol{\varnothing} / \ldots \mathrm{nV} \#
$$

The rule in (19) specifies that the vowel at noun stem final position deletes before a plural suffix.

It is worth noting that apart from the stem-final vowel deletion resulting from the process of suffixation, we also noticed that there are other sets of nouns whose final vowel shows resistance to the deletion phenomenon. However, a close appraisal of the C'lela data shows appreciable cases of vowel retention in Riba dialect, a variety spoken at the periphery. This is to say, that stem-final vowel deletion, as confirmed in Aliero (2013), is prevalent in the Zuru dialect, which is the central dialect. Additionally, it can be noted that the process of plural formation of the animate nouns sometimes triggers tonal modification of the input stem, whereas the plural suffix, "has low tone lexically assigned to it" Dettweiler (2012:23-24) with a few occurring with a falling tone. 
This vowel deletion phenomenon seems to be restricted to a few languages in the Niger-Congo family. Some of the occurrences of vowel deletion process somehow similar to C'lela in (18) obtain in Kambari (Stark 2010: 51), and Lobala [loq], a Bantu language of Zaïre (Morgan 1993: 51). In Kambari, when two vowels come together across morpheme boundaries, the first vowel is deleted, and the second one is realized as in (20), while for Lobala, Morgan (1993) shows that the addition of the stative verbal extension suffix to the verb, for the derivation of the stative verbal forms, results in the deletion of the verb stem final-vowel as in (21). The motivation for the vowel deletion from Kambari and Lobala differs from that of C'lela, in that the deletion occurs in these languages only when two vowels merge at a boundary, which is not the case in C'lela. Consider the following examples:

\section{Kambari}

(20) a. /ikebe i le/

$$
\begin{aligned}
& \text { money NCM their [ikeb-ile] 'their money' } \\
& \text { b. /urana u və/ day NCM my [uran-uvə] 'my day' } \\
& \text { d. /ulinga u le/ work NCM their [uling-ule] 'their work'. }
\end{aligned}
$$$$
\text { c. /ucira u və/ power NCM my [ucir-ovə] 'my power' }
$$

\begin{tabular}{|c|c|c|}
\hline $\begin{array}{l}\text { STEM } \\
\text { a. bul-a } \\
\text { b. cil-a } \\
\text { c. zol-a } \\
\text { d. wal-a }\end{array}$ & 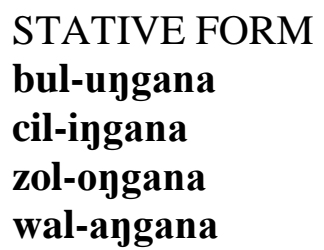 & $\begin{array}{l}\text { GLOSS } \\
\text { 'be mixed up' } \\
\text { 'hurry' } \\
\text { 'be stirred' } \\
\text { 'fall from a height' }\end{array}$ \\
\hline
\end{tabular}

(Stark 2010: 51)

\section{Lobala}

(Morgan 1993: 51)

\subsection{Conclusion}

The paper has explored the phonological processes taking place in noun inflection in C'lela. They include vowel-copying, metathesis, vowel lengthening, and final-vowel deletion. In addition, it was shown that C'lela has a distinctive inflectional feature. This is evident in a few phonological requirements or conditions that must be met for phonological processes to occur in plural formation, as in the case of metathesis, as well as the rules, which stipulate that the short vowels of monosyllabic nouns encounter lengthening when succeeded by a suffix plural marker. 


\section{References}

Aliero, Muhammad A., 2013. Aspects of the Morphology of C'lela. PhD Thesis. Department of Linguistics, University of Ghana, Legon.

Anttila, Arto and Adams Bodomo, 2007. Prosodic morphology in Dagaare. In Fiona McLaughlin, Eric Potsdam, and Masangu Matondo, eds., Selected Proceedings of the $38^{\text {th }}$ Annual Conference on African Linguistics (ACAL 38), pp. 56-68. Cascadilla Proceedings Project, Somerville, Massachusetts, 2009. http://www.lingref.com/cpp/acal/38/paper, accessed September 7, 2012.

Aronoff, Mark, 1976. Word Formation in Generative Grammar. Cambridge, MA: MIT Press.

Baba, Ahmad Tela 1998. The Morphophonological Alternations in the Hausa Verbal Form Frankfurt am Main.

Barnwell, Katherine, 1998. Course Notes on the Introductory Course in Applied Linguistics. Jos: Nigeria Bible Translation Trust.

Blench, Roger M. and J. Stuart McGill, n.d., The West Kainji Languages of Northwestern and Central Northern Nigeria: Comparative Wordlists.

http://www.rogerblench.info/language\%20data/Niger-Congo/Benue-

CongoWest\%20/Kainji.

Buckley, Eugen, 2011. Metathesis. In Marc Van-Ootendorp, Colin J. Ewen, Elizabeth Hume and Karen Rice, eds., The Blackwell Companion to Phonology, Volume 1. London: Blackwell. www.companiontophonology.com/subscriber/ accessed April 15, 2013.

Crozier, David, 2012. From verb morphology to discourse in Central Kambari. In Roger M. Blench and Stuart McGill, eds., Advances in Minority Languages in Nigeria, vol. 1 pp. 325-65. Köln: Rüdiger Köppe.

Crystal, David, 2008. A Dictionary of Linguistics and Phonetics (3rd edition). London: Blackwell.

Chomsky, Noam A. and Morris Halle, 1968. The Sound Pattern of English. New York: Harper and Row.

Dettweiler, Stephen H., 2012. C'lela Grammar Sketch. Manuscript, Zuru.

Gerhardt, Ludwig, 1989. Kainji and Platoid. In J. Bendor-Samuel, ed., The Niger-Congo Languages pp. 359-376. Lanham, Maryland: University Press of America..

Goldsmith, John, 1976. Autosegmental Phonology. PhD Dissertation, Massachusetts Institute of Technology.

Harley, Matthew, 2012. Unusual sounds in Nigerian languages. In Roger M. Blench and Stuart McGill, eds., Advances in Minority Languages in Nigeria, vol. 1, pp. 39- 66. Köln: Rüdiger Köppe.

Hoffmann, Carl, 1967. An outline of the Dakarkari noun class system and the relation between prefix and suffix noun class systems. In G. Manessy, ed., La Classification 
Nominale dans les Langues Négro-Africaines, pp. 237-259. Paris: Editions du Centre Nationale de la Recherche Scientifique.

Hume, Elizabeth, 2001. Metathesis: formal and functional considerations. In Elizabeth Hume, Norval Smith and Jeron van de Weijer, Surface Syllable Structure and Segment Sequencing, pp. 1-25, HIL Occasional Papers, Leiden, NL: HIL. www.ling.ohio-state.edu/ehume/Hume.cv, accessed April 20, 2012.

Hume, Elizabeth, 2004. The indeterminacy/attestation model of metathesis. Language 80.2.

Hume, Elizabeth, 2007. The interaction of internal and external factors in metathesis and deletion. Conference on Precedence Relations, CUNY Phonology Forum 9.

Hume, Elizabeth and Jeff Mielke, 2001. Consequences of word recognition for metathesis. In Hume et al. eds. (2001), pp. 135-158. www.ling.ohio-state.edu/-ehume/Hume.cv, accessed May 6, 2012.

Hyman, Larry M., 2007. Niger-Congo verb extensions: overview and discussion. In Doris L. Payne and Jaime Peña, eds., Selected Proceedings of the $37^{\text {th }}$ Annual Conference on African Linguistics, 149-163, Somerville, MA: Cascadilla Proceedings Projects. http://www.lingref.com. Accessed November 23, 2012.

Kenstowicz, Michael, 1994. Phonology in Generative Grammar. Cambridge: Blackwell Publishers.

Lewis, M. Paul, Gary F. Simons and Charles D. Fenning, eds., 2015. Ethnologue: Languages of the World, Sixteenth Edition. Dallas, Texas: Summer Institute of Linguistics.

McGill, Stuart J. (2009). Gender and Person Agreement in Cicipu Discourse. PhD Dissertation. The School for Oriental and African Studies, University of London.

McGill, Stuart J. and Roger M. Blench, 2012. Documentation, development and ideology in the Northwest Kainji languages. In Peter K. Austin and Stuart J. McGill, eds., Language Documentation and Description 11, pp. 90-135. London.

Morgan, David, 1993. Vowel harmony, syllable structure, and causative extension in Lobala: a government phonology account. Journal of West African Languages 23.3: 46-63. http://www.journal.JWAL-23-1-morgan, accessed November 12, 2012.

Onukawa, M. C., 1999. The order of extensional suffixes in Igbo. Afrikanistische Arbeitspapiere 59: 109-129.

Rose, Sharon and Rachel Walker, 2011. Harmony systems (Chapter 8). In John Goldsmith, Jason Riggle, and Alan C. L. Yu, eds., The Handbook of Phonological Theory, Second Edition. Vol. 75. West Sussex: Willy-Blackwell.

Simons, Garry F., 1994. Principles of multidialectal orthography design. Notes on Literacy 20.2: 13-32.

Smith, Rabecca D., 2007. The Noun Class System of ut.Ma'in: A West Kainji Language of Nigeria. M. A. Thesis, University of North Dakota. 
Aliero: Morphophonology of C'Lela nouns

Stark, Janie P., 2010. Kambari Orthography Design. SIL, SIL International. http://www01.sil.org/silepubs/52284/stark_OrthographyDesign_52284.pdf accessed November 10, 1012.

Williamson, Kay, 1984. Practical Orthography in Nigeria. Ibadan: Heinemann.

Williamson, Kay, 1989. Niger-Congo overview. In J. Bendor-Samuel, ed., The Niger-Congo Languages pp. 247-274. Lanham Maryland: The University Press of America. 